\title{
How do community responses from global south contribute to climate justice and resilience debate?
}

\author{
Fabiana Barbi Seleguim
}

${ }^{I}$ Núcleo de Estudos e Pesquisas Ambientais, Nepam, Unicamp, Campinas, SP, Brasil

\begin{abstract}
Towards a just climate change resilience: Developing resilient, anticipatory and inclusive community response" fills an important gap in literature about climate justice and community responses by focusing its lenses in the global south. Designedly, the chapters cover the issue in all the continents where territories and their populations are located in the global south: Brazil and Uruguay (South America), Bangladesh (Asia), Mozambique (Africa) and Solomon Islands (Oceania). The biggest lesson learned from the cases is that strengthening the role of communities and multi-stakeholder coalitions is essential to reduce the injustices and inequalities inherent in anthropogenic climate change, in the face of deforestation, water contamination, declining catches, political instabilities and other economic impacts.
\end{abstract}

Keywords: Climate change; climate resilience; climate justice; community response; resilient societies.

Book reviwed: Torres, Pedro Henrique Campello; Jacobi, Pedro Roberto (Eds.). Towards a just climate change resilience: Developing resilient, anticipatory and inclusive community response. Palgrave Studies in Climate Resilient Societies. Palgrave Macmillan. 2021.

São Paulo. Vol. 24, 2021

Review

DOI: http://dx.doi.org/10.1590/1809-4422asoc20210148vu2021L5RS 


\section{Introduction}

The book "Towards a just climate change resilience: Developing resilient, anticipatory and inclusive community response" organized by Pedro H. C. Torres and Pedro R. Jacobi was written during the most significant health crisis in contemporaneity - the COVID-19 pandemic and debates one of the most challenging facts of our history: climate change. Its main objective is to understand how community responses from global south contribute to climate justice and resilience debate.

While climate change is a global problem, not everyone has the same levels of responsibility for its most worrisome manifestations. Henceforth, the importance of demanding climate justice, as well as addressing the climate boundary transgression, which has almost no return (STEFFEN et al., 2015; WHYTE, 2019). More than that, climate justice links human rights and development to achieve a human-centered approach, safeguarding the rights of the most vulnerable people and sharing the burdens and benefits of climate change and its impacts equitably and fairly (ROBINSON and SHINE, 2018).

Therefore, the construction of just climate change resilience is closely related to the pursuit of guaranteeing human rights such as the right to life, health, education, housing, among others. Gender equality and reducing inequalities constitute Sustainable Development Goals (SDG 5 and SDG 10 respectively). Furthermore, by incorporating these issues, climate planning will contribute to achieving other SDGs, such as quality health (SDG 3), clean water and sanitation (SDG 6), sustainable cities and communities (SDG 11), among others.

In a world facing a climate emergency the questions that stand are: how to address multidimensional vulnerability in territories where multiple pressures have been reinforcing each other and surpassing resilience tipping points and what direction to take in under such circumstances?

In total, fifteen authors from various universities in the world contribute to this debate in the six chapters of the publication. This collection of studies fills an important gap in literature about climate justice and community responses by focusing its lenses in the global south (BAI et al. 2018).

The editors introduce the subject by discussing that the global south is highly heterogeneous in all its spheres and layers. Designedly, the chapters cover the issue of climate justice and community responses in all the continents where territories and their populations are located in the global south: Brazil and Uruguay (South America), Bangladesh (Asia), Mozambique (Africa) and Solomon Islands (Oceania). The result is a truly interdisciplinary and multi-ethnic effort of dialogue and learning.

Even though the authors acknowledge the inequitable realities of climate vulnerability among countries in the global south, they highlight the capacities of agency among local communities, organizations and peoples. The five cases presented address a variety of issues: small-scale fishers' adaptive capacity through participatory action research (Uruguay); water security for climate vulnerable communities (Bangladesh); forest-based carbon offset initiatives in building just and resilient territories (Solomon 
Islands); resilience in extremely vulnerable territories (Mozambique) and just transition in a climate emergency scenario (Brazil).

The cases make clear the challenges of countries in the global south to face climate injustices and reduce the risks of aggravating current vulnerabilities, as well as to promote strategies to generate social inclusion, transparency in adopted policies and risk reduction at different scales and scopes. Despite their specificities, these cases bring a common ground: the importance of the active participation of communities in building resilience and climate justice.

In this direction, the biggest lesson learned from the cases is that strengthening the role of communities and multi-stakeholder coalitions is essential to reduce the injustices and inequalities inherent in anthropogenic climate change, in the face of deforestation, water contamination, declining catches, political instabilities and other economic impacts. This implies the need to look deeper into the current resilience and adaptive capacity of vulnerable communities and the different indicators that range from institutional setting to socio-environmental vulnerabilities to be addressed to promote real transformations in people's lives facing climate challenges. Moreover, illuminating insurgent, non-state, community practices, traditional knowledge is fundamental in this process.

In a nutshell, the contributors of this volume remind us that climate justice requires engaging with an entire suite of problems and solutions in sectors as varied as forests, fisheries, drinking water supply, climate action plans, and intersectional vulnerabilities that result when the climate crisis intervenes in politically unstable regions that have also been at the receiving end of transnational extractive regimes.

There is no ready recipe to achieve just climate change resilience. However, this publication shows one essential ingredient in this process: community involvement. The impacts of climate change do not affect everyone equally in a country, region, city, community or even in the same family. This is because the inequalities built by gender relations, ethnicity, age group, color, race and economic status imply different levels of vulnerability and, consequently, different levels of adaptive capacity and resilience (TERRY, 2009; HARPER, 2019; WHYTE, 2019; PORTER et al., 2020). Therefore, it is essential to identify the roles assumed by each of these groups in relation to vulnerability and risk reduction when considering adaptation and resilience strategies. And in this direction, there is a lot to be done.

This is a highly relevant contribution that inspires more research, debates and new practices in the face of the climate emergency we have been experiencing, mainly regarding the multitude of complexities raised by climate change impacts for policy and decision-makers. Time is crucial and one of the main messages of the IPCC report is the "unprecedented speed" of climate change (IPCC, 2021), which adds more spice into climate justice pursuit.

\section{Acknowledgments}

This work has been supported by CAPES National Postdoctoral Program (PNPD). 


\section{References}

Bai, X. R.; Dawson, R. J.; Ürge-Vorsatz, D.; Delgado, G. C.; Barau, A. S.; Dhakal, S.; Dodman, D.; Leonardsen, L.; Masson- Delmotte V.; Roberts, D. C.; et al. Six research priorities for cities and climate change. Nature, 555 (7694), 23-25, 2018.

Harper, S. The Convergence of Population Ageing with Climate Change. Journal of Population Ageing 12, 401-403, 2019.

IPCC. Summary for Policymakers. In: Climate Change 2021: The Physical Science Basis. Contribution of Working Group I to the Sixth Assessment Report of the Intergovernmental Panel on Climate Change [MassonDelmotte, V., P. Zhai, A. Pirani, S. L. Connors, C. Péan, S. Berger, N. Caud, Y. Chen, L. Goldfarb, M. I. Gomis, M. Huang, K. Leitzell, E. Lonnoy, J. B. R. Matthews, T. K. Maycock, T. Waterfield, O. Yelekçi, R. Yu and B. Zhou (eds.)]. Cambridge University Press. 2021.

Porter, L., Rickards, L., Verlie B., Bosomworth, K., Moloney, S., Lay B., Latham B., Anguelovski I. \& Pellow D. Climate Justice in a Climate Changed World, Planning Theory \& Practice, 21:2, 293-321, 2020.

Robinson, M., Shine, T. Achieving a climate justice pathway to $1.5^{\circ} \mathrm{C}$. Nature Clim Change 8 , 564-569. 2018.

Steffen, W., Richardson, K., Rockström, J., Cornell, S.E., Fetzer, I., Bennett, E.M. , Biggs, R., Carpenter, S.R., Vries, W. de, Wit, C.A. de, Folke, C., Gerten, D. , Heinke, J., Mace, G.M., Persson, L.M., Ramanathan, V., Reyers, B. and Sörlin, S. Planetary boundaries: Guiding human development on a changing planet. Science 347:6219. 2015.

Terry, G. No climate justice without gender justice: an overview of the issues, Gender $\mathbb{\&}$ Development, 17:1, 5-18, 2009.

Whyte, K. Too late for indigenous climate justice: Ecological and relational tipping points. WIREs Clim Change;11:e603. 2019. 


\section{Fabiana Barbi Seleguim}

$\varangle$ fabarbi@gmail.com

ORCiD: https://orcid.org/0000-0003-4531-3513
Submitted on: $20 / 08 / 2021$

Accepted on: 02/09/2021

2021;24e:0148

How to cite: SELEGUIM, F. B. How do community responses from global south contribute to climate justice and resilience debate? Ambiente \& Sociedade. São Paulo, v. 24, p. 1-05, 2021. 


\title{
Como as respostas das comunidades do sul global contribuem para o debate sobre justiça climática e resiliência?
}

\author{
Fabiana Barbi Seleguim
}

São Paulo. Vol. 24, 2021

Resenha

\begin{abstract}
Resumo: "Towards a just climate change resilience: Developing resilient, anticipatory and inclusive community response" preenche uma lacuna importante na literatura sobre justiça climática e respostas da comunidade, concentrando suas lentes no sul global. De maneira planejada, os capítulos cobrem o tema em todos os continentes onde os territórios e suas populações estão localizados no sul global: Brasil e Uruguai (América do Sul), Bangladesh (Ásia), Moçambique (África) e Ilhas Salomão (Oceania). A maior lição aprendida com os casos é que fortalecer o papel das comunidades e coalizões de múltiplas partes interessadas é essencial para reduzir as injustiças e desigualdades inerentes às mudanças climáticas antropogênicas, diante do desmatamento, contaminação da água, diminuição da pesca, instabilidades políticas e outros impactos econômicos.
\end{abstract}

Palavras-chave: Mudanças climáticas; resiliência climática; justiça climática; respostas das comunidades; sociedades resilientes.

Como citar: BARBI, F. Como as respostas das comunidades do sul global contribuem para o debate sobre justiça climática e resiliência Ambiente \& Sociedade. São Paulo, v. 24, p. 1-05, 2021. 


\title{
¿Cómo contribuyen las respuestas de la comunidad del sur global al debate sobre la justicia climática y la resiliencia?
}

\author{
Fabiana Barbi Seleguim
}

São Paulo. Vol. 24, 2021

Resenha
Resumen: "Towards a just climate change resilience: Developing resilient, anticipatory and inclusive community response" llena un vacío importante en la literatura sobre la justicia climática y las respuestas comunitarias al enfocar sus lentes en el sur global. Diseñados, los capítulos cubren el tema en todos los continentes donde los territorios y sus poblaciones se encuentran en el sur global: Brasil y Uruguay (América del Sur), Bangladesh (Asia), Mozambique (África) e Islas Salomón (Oceanía). La mayor lección aprendida de los casos es que fortalecer el papel de las comunidades y las coaliciones de múltiples partes interesadas es esencial para reducir las injusticias y desigualdades inherentes al cambio climático antropogénico, frente a la deforestación, la contaminación del agua, la disminución de las capturas, la inestabilidad política y otros impactos económicos.

Palabras-clave: Cambio climático; resiliencia climática; justicia climática; respuesta comunitaria; sociedades resilientes.

Como citar: BARBI, F. ¿Cómo contribuyen las respuestas de la comunidad del sur global al debate sobre la justicia climática y la resiliencia? Ambiente \& Sociedade. São Paulo, v. 24, p. 1-05, 2021.

DOI: http://dx.doi.org/10.1590/1809-4422asoc20210148vu2021L5RS 